\title{
Protein sources for crossbred dairy cows in the semiarid
}

\author{
Viviany Lúcia Fernandes dos Santos ${ }^{1}$, Marcelo de Andrade Ferreira², Adriana Guim², Fabiana \\ Maria da Silva', Stela Antas Urbano' ${ }^{1}$, Emmanuelle Cordeiro da Silva ${ }^{1}$
}

\footnotetext{
${ }^{1}$ Programa de Pós-Graduação em Zootecnia, Universidade Federal Rural de Pernambuco, Recife, PE.

${ }^{2}$ Departamento de Zootecnia - UFRPE.
}

\begin{abstract}
Alternative sources of protein for lactating cows were evaluated in this study with respect to intake, digestibility, milk yield and milk composition. Eight multiparous Holstein/Gyr cows were simultaneously distributed in two $4 \times 4$ latin squares. Each experimental period lasted 21 days (14 days for adaptation and seven days to collect data and samples). Three protein sources, cottonseed meal, semi-integral soybean meal and corn steep liquor were evaluated and soybean meal was used as a control. When the corn steep liquor was used, lower intakes of dry matter, organic matter, crude protein and total digestible nutrients were observed compared with soybean meal. Animals that consumed corn steep liquor had a lower milk yield than those fed soybean meal, and no treatment effect on the milk fat content was detected. Animals that consumed cottonseed meal and corn steep liquor had a lower fat yield than those fed soybean meal. Feeding with semi-integral soybean meal decreased the milk protein percentage compared with soybean meal. Nutrient digestibility was lower for cows fed diets with corn steep liquor, except for crude protein digestibility, which was higher for animals fed cottonseed meal and semiintegral soybean meal compared with those fed soybean meal. Based on the dry matter intake, milk yield and milk components, soybean meal can be replaced with semi-integral soybean meal.
\end{abstract}

Key Words: by-product, digestibility, intake, milk yield

\section{Introduction}

The semi-arid region of Northeast Brazil, given its ability to withstand the harsh environment, provides more conditions for dairy cattle rearing compared with other agricultural activities. Therefore, this activity accounts for the setting of men on field and generation of employment and income (Ferreira et al., 2009). The northeast semiarid region is defined by seasonal food production due to the low and irregular rainfall. Forages able to tolerate long periods without rain are necessary to maintain milk yield throughout the year, and supplementation with concentrates is important to meet the nutritional requirements of the animals.

Soybean meal is traditionally fed as a protein concentrate, but both its use in human feeding and in non-ruminant rations, as well as the difficulty of its production in semiarid regions, have restricted its use. Moreover, the price of soybean is controlled by the international market due to the high demand by consumers, thus the search for alternative feedstuffs that do not affect animal performance and that ensure the economic viability of the production system is important.

Chemical composition, feed palatability, shipping costs, product storage and product availability in the area throughout the year are important aspects that should be considered when choosing alternative feeding sources. Santos et al. (1998) affirmed that microbial protein has the best amino acid profile available for milk synthesis and production, with soybean meal as the second best. However, some authors reported that other protein concentrates, such as whole cottonseed and cottonseed meal, can replace soybean meal with no negative effects on animal performance (Alves, 2008; Silva, 2008; Pina et al., 2006).

The industrialization of corn produces corn steep liquor as a by-product, which has been commercialized for the animal sector as a source of protein (approximately 50\% protein) especially because of its low cost and availability.

In this study, the effect of feeding three different protein sources, cottonseed meal, semi-integral soybean meal and corn steep liquor, were evaluated on the intake, total tract apparent digestibility of nutrients, milk yield and milk composition of lactating cows.

\section{Material and Methods}

This trial was conducted on the Várzea Alegre farm, located in the municipality of Pesqueira, in the microregion of Vale do Ipojuca, Northeast Brazil. The rainy 
season occurs from March to May, with an average rainfall of $584 \mathrm{~mm}$. The mean monthly temperature ranges from 26.3 to $32.2{ }^{\circ} \mathrm{C}$ (ITEP, 2009).

Eight crossbred 3/4 (Holstein/Gyr) multiparous cows (average body weight of $616 \pm 80 \mathrm{~kg}$ ) in mid-lactation (140 days of milk) were housed in individual pens with drinkers and troughs. The trial (84 days) was conducted from January 14th to April 7th, 2010. Each experimental period lasted 21 days, with the first 14 days for adaptation to the diet followed by seven days for data collection. The animals were weighed at the beginning of each experimental period.

The following protein sources (Tables 1 and 3) were evaluated: high fat cottonseed meal, extruded semi-integral soybean meal, corn steep liquor and soybean meal (control). The soybean meal-based diet was formulated according to recommendations of the NRC (2001) to meet an average daily milk yield of $25 \mathrm{~kg}$, with $3.5 \%$ of fat, which is required by mid-lactating dairy cows. The concentrates were formulated to contain $40 \%$ of each protein source (dry matter basis) and the crude protein content (approximately $30 \%$ crude protein (CP), dry matter basis) was adjusted by adding urea to obtain diets with $15 \% \mathrm{CP}$ in the dry matter basis (Table 2).

To obtain the cottonseed meal, the whole cottonseed is placed in a screw conveyor where it will be cleaned, undergo a process of breaking and smashing (mill and hammer), and be baked at $90{ }^{\circ} \mathrm{C}$. Then the baked product undergoes a process of mechanical pressing, resulting in the cake and the cottonseed oil, so the product is bagged and stored.

To produce the semi-integral soybean meal, the grains are ground through hammer mill, where they are broken down and their temperature is increased to approximately $40{ }^{\circ} \mathrm{C}$. After grinding, the soybean meal is disposed in a heating tank that maintains a temperature between 40 and
$48{ }^{\circ} \mathrm{C}$. The product is then sent to the soybean extruder. After the extrusion, the product is baked at approximately $70{ }^{\circ} \mathrm{C}$, placed in the press to remove the oil, and finally bagged.

The industrialization of corn produces the residue of corn steep liquor, which has been commercialized for the animal sector. The corn grain is macerated at $50-55{ }^{\circ} \mathrm{C}$, for 42 hours. The process conditions permit the growth of Lactobacillus sp., which uses the soluble sugars in the steep water to produce lactic acid, lowering the $\mathrm{pH}$ and promoting conditions to separate the components of the grain (Lopes Filho, 1999). The steep liquor, initially containing approximately $60 \mathrm{~g} / \mathrm{kg}$ solid, evaporated until $450-500 \mathrm{~g} / \mathrm{kg}$ dry matter.

The experimental diets were provided twice a day (06h00min a.m. and 03h00min p.m.), and they were adjusted daily according to the consumption of the previous day, allowing leftovers of approximately $12 \%$ of the total from the dry matter provided. Feed and leftovers were sampled daily during the fecal collection period. At the end of this period, one composite sample was made per treatment.

The semi-automatic (milking pail) milking was performed twice a day $(05 \mathrm{~h} 30 \mathrm{~min}$ a.m. and $02 \mathrm{~h} 30 \mathrm{~min}$ p.m. to determine the milk yield, and milk production was recorded.

Fecal dry matter output was estimated using LIPE $^{\circledR}$ (modified and enriched hydroxyphenylpropane - purified lignin eucalyptus) as an external marker to calculate total tract apparent digestibility of the feed nutrients (Lima et al., 2008). The marker was administered in the form of capsules (500 mg/animal/d) over seven days (two days for adaptation followed by five days for data collection) in the morning, at 06h00min a.m. (single dose). The fecal samples were collected once a day from each animal, on the $1 \mathrm{st}$, $2 \mathrm{nd}, 3 \mathrm{rd}$, 4th and 5 th days of the collection period, at $6 \mathrm{~h} 00$, $8 \mathrm{~h} 00,10 \mathrm{~h} 00,12 \mathrm{~h} 00$ and $2 \mathrm{~h} 00$, respectively. All samples

Table 1 - Chemical composition of feedstuffs

\begin{tabular}{|c|c|c|c|c|c|c|}
\hline Ingredient & $\begin{array}{l}\text { Dry matter (DM) } \\
\mathrm{g} / \mathrm{kg}\end{array}$ & $\begin{array}{l}\text { Organic matter, } \\
\text { g/kg DM }\end{array}$ & $\begin{array}{l}\text { Crude protein, } \\
\text { g/kg DM }\end{array}$ & $\begin{array}{c}\text { Ether extract, } \\
\text { g/kg DM }\end{array}$ & $\begin{array}{l}\text { Neutral detergent } \\
\text { fiber, g/kg DM }\end{array}$ & $\begin{array}{c}\text { Non-fiber } \\
\text { carbohydrates, g/kg } \\
\text { DM }\end{array}$ \\
\hline Soybean meal & 867.6 & 923.6 & 480.0 & 227.0 & 250.0 & 170.9 \\
\hline Cottonseed meal & 937.5 & 933.7 & 304.5 & 110.0 & 4788 & 404.0 \\
\hline Semi-integral soybean meal & 936.9 & 923.4 & 436.0 & 108.3 & 207.5 & 171.6 \\
\hline Corn steep liquor & 428.2 & 837.0 & 475.2 & 06.0 & 000 & 355.8 \\
\hline Ground corn & 899.8 & 972.1 & 90.2 & 40.5 & 136.2 & 705.2 \\
\hline Wheat bran & 901.1 & 934.0 & 167.4 & 35.1 & 417.2 & 314.1 \\
\hline Cottonseed & 939.5 & 966.8 & 242.3 & 219.7 & 460.6 & 44.2 \\
\hline Spinelless cactus* & 92.4 & 861.8 & 30.2 & 14.2 & 291.0 & 526.4 \\
\hline Buffel silage & 250.5 & 881.0 & 81.0 & 24.0 & 672.9 & 103.1 \\
\hline Cassava peel & 361.6 & 864.2 & 59.0 & 08.6 & 219.8 & 576.8 \\
\hline
\end{tabular}

DM - dry matter; OM - organic matter; CP - crude protein; EE - ether extract; NDF - neutral detergent fiber; NFC - non-fiber carbohydrates.

* Opuntia ficus indica Mill. 
Table 2 - Composition of the three concentrates in the dry matter basis

\begin{tabular}{lcccc}
\hline \multirow{2}{*}{$\begin{array}{l}\text { Ingredient } \\
\text { (g/kg dry matter) }\end{array}$} & $\begin{array}{c}\text { Soybean } \\
\text { meal }\end{array}$ & $\begin{array}{c}\text { Cottonseed } \\
\text { meal }\end{array}$ & $\begin{array}{c}\text { Semi-integral Corn steep } \\
\text { soybean meal }\end{array}$ & $\begin{array}{c}\text { Protein source } \\
\text { liquor }\end{array}$ \\
\cline { 2 - 5 } Soybean meal & 400 & - & - & - \\
Cottonseed meal & - & 400 & - & - \\
Semi-integral soybean & & & & - \\
meal & - & - & 400 & 400 \\
Corn steep liquor & - & - & - & 450 \\
Ground corn & 450 & 450 & 450 & 980 \\
Wheat bran & 100 & 680 & 900 & 170 \\
Urea & 150 & 470 & 250 & 350 \\
Mineral mix & 350 & 350 & 350 & \\
\hline
\end{tabular}

Table 3 - Experimental diet composition in the dry matter basis

\begin{tabular}{lcccc}
\hline \multirow{2}{*}{$\begin{array}{l}\text { Ingredient, } \\
\text { g/kg DM }\end{array}$} & \multicolumn{4}{c}{ Protein source } \\
\cline { 2 - 5 } & $\begin{array}{c}\text { Soybean } \\
\text { meal }\end{array}$ & $\begin{array}{c}\text { Cottonseed Semi-integral } \\
\text { meal }\end{array}$ & $\begin{array}{c}\text { Corn steep } \\
\text { soybean meal }\end{array}$ & liquor \\
\hline Concentrate & 310 & 310 & 310 & 310 \\
Whole cottonseed & 110 & 110 & 110 & 110 \\
Cactus & 300 & 300 & 300 & 300 \\
Buffel grass silage & 140 & 140 & 140 & 140 \\
Cassava peel & 140 & 140 & 140 & 140 \\
Chemical composition & & & & \\
Dry matter (DM), g/kg & 213.2 & 215.3 & 215.1 & 206.1 \\
Organic matter $^{1}$ & 881.9 & 884.3 & 882.5 & 871.5 \\
Crude protein $^{1}$ & 148.2 & 155.5 & 154.1 & 150.5 \\
Ether extract $^{1}$ & 43.8 & 54.2 & 54.5 & 42.3 \\
Neutral detergent fiber $^{1}$ & 335.8 & 358.7 & 328.5 & 307.6 \\
Non-fiber carbohydrates $^{1}$ & 354.0 & 315.6 & 345.5 & 371.1 \\
\hline
\end{tabular}

${ }^{1} \mathrm{~g} / \mathrm{kg}$ of dry matter.

were frozen at $-20{ }^{\circ} \mathrm{C}$ and sent to the Animal Nutrition Lab UFRPE, located in the city of Recife (Northeast Brazil), The samples were, oven-dried at $65^{\circ} \mathrm{C}$ for $72 \mathrm{~h}$ and ground using a Wiley mill with a $1 \mathrm{~mm}$ screen. After drying the samples, they were mixed to obtain a sample of the dry matter basis. The fecal samples were analyzed by infra-red spectroscopy at the Animal Nutrition Lab - UFMG, located in the city of Belo Horizonte, Brazil.

The feed samples were analyzed for dry matter (DM), ash (MM), total nitrogen (TN) and ethereal extract (Silva \& Queiroz, 2002) as well as for neutral (NDF) and acid (ADF) detergent fibers (Van Soest et al., 1991), using non-woven textile bags (Detmann et al., 2012) made in the Nutrition Lab - UFRPE, and autoclave (Senger et al., 2008). The leftovers, concentrate and roughage were analyzed for NDF by adding three drops $(50 \mu \mathrm{L})$ of $\alpha$-amylase to each sample during washing with detergent and water, following the recommendations proposed by Van Soest et al. (1991).

The non-fiber carbohydrates were calculated using the formula proposed by Weiss (1999); 100- (\%NDF + \% CP + $\% \mathrm{EE}+\% \mathrm{ash})$. The total digestible nutrients intake (TDNI) was calculated using the equation proposed by Sniffen et al. (1992): TDNI $={ }_{D} \mathrm{CPI}+{ }_{\mathrm{D}} \mathrm{TCHI}+\left(2.25 \times{ }_{\mathrm{D}} \mathrm{EEI}\right)$, in which: ${ }_{\mathrm{D}} \mathrm{CPI}=$ digestible crude protein intake, ${ }_{\mathrm{D}}^{\mathrm{TCHI}}=$ digestible total carbohydrate intake, and ${ }_{D} \mathrm{EEI}=$ digestible ether extract intake. The TDN levels were estimated by the relationship between the consumption of TDN and dry matter intake.

Milk yield (MY) was individually recorded and the $3.5 \%$ of fat-corrected milk yield (FCM) was calculated using the following equation: $\mathrm{FCM}=(0.432+0.1625 \times \%$ milk fat $) \times$ MY $(\mathrm{kg} / \mathrm{d})($ Sklan et al., 1991). Individual feed efficiency was evaluated as the average $3.5 \%$ fat corrected milk yield/average DM intake ratio of each experimental period (Valadares Filho et al., 2000). Following the same procedure, the nitrogen utilization efficiency was obtained by dividing the average milk total-N by the average diet total-N ingestion (Broderick, 2003).

Milk samples were individually collected on the 6th and 7th days of each period in proportion to the milking production (1\%). Morning samples were packed in plastic bags, labeled and kept at $4{ }^{\circ} \mathrm{C}$. After the evening sampling, composite and homogeneous samples were packed in $50 \mathrm{~mL}$ plastic bottles, labeled and conserved with Bronopol ${ }^{\mathbb{Q}}$. Following collection, the samples were analyzed for fat, protein, lactose and total solids at the PROGENE lab (Programa de Gerenciamento de Rebanhos Leiteiros do Nordeste) of the Departamento de Zootecnia of Universidade Federal Rural de Pernambuco - UFRPE, located in the city of Recife, in Northeast Brazil.

Two $4 \times 4$ latin squares with cows allotted according to milk yield (one square with cows producing $25 \mathrm{~kg} /$ day and another with cows producing $20 \mathrm{~kg}$ /day) were used. Analysis of variance (ANOVA) was performed using the software Sistema de Análises Estatísticas e Genéticas SAEG (Statistical and Genetics Analysis System, version 8.0 ) with a $5 \%$ level of significance. Comparisons of means were made using the Dunnett test.

\section{Results and Discussion}

The dry matter intake was lower $(\mathrm{P}<0.05)$ for animals fed corn steep liquor than for those fed the control. Animals fed diets with cottonseed meal and whole extruded soybean did not differ $(\mathrm{P}>0.05)$ from those fed the control (Table 4).

These findings can be explained by some of the mechanisms that control the selection and feed ingestion by cattle. Mertens (1994) suggested three theories of intake regulation: the physiological, defined by the nutritional balance, the physical, related to the ability of rumen distention, and the psychogenic, which represents 
Table 4 - Effect of alternative protein sources on nutrient intake of dairy cows

\begin{tabular}{|c|c|c|c|c|c|c|}
\hline \multirow[b]{2}{*}{ Item } & \multicolumn{4}{|c|}{ Protein sources } & \multirow[b]{2}{*}{$\mathrm{P}$ value } & \multirow[b]{2}{*}{$\mathrm{CV}(\%)$} \\
\hline & Soybean meal & Cottonseed meal & $\begin{array}{l}\text { Semi-integral } \\
\text { soybean meal }\end{array}$ & Corn steep liquor & & \\
\hline \multicolumn{7}{|c|}{ Intake $(\mathrm{kg} / \mathrm{d})$} \\
\hline Dry matter & 21.03 & 20.73 & 20.60 & $18.86^{*}$ & 0.001 & 4.77 \\
\hline Organic & 18.54 & 18.35 & 18.19 & $16.47 *$ & 0.000 & 4.75 \\
\hline Crude protein & 3.12 & 3.32 & 3.21 & $2.75^{*}$ & 0.000 & 6.50 \\
\hline Non-fibrous carbohydrates & 7.99 & $6.94 *$ & $7.53 *$ & $7.49 *$ & 0.000 & 4.34 \\
\hline Total digestible nutrients & 14.36 & 14.55 & 14.62 & $11.46^{*}$ & 0.000 & 5.78 \\
\hline \multicolumn{7}{|c|}{ Intake (g/kg BW) } \\
\hline Dry matter & 33.1 & 33.0 & 32.7 & $30.2 *$ & 0.004 & 47.7 \\
\hline Neutral detergent fiber & 10.2 & $11.0 *$ & 09.9 & $08.7 *$ & 0,000 & 68.8 \\
\hline
\end{tabular}

Means in a row differ $(\mathrm{P}<0.05)$ from control by the Dunnett test.

$\mathrm{BW}$ - body weight; CV - coefficient of variation.

the animal behavioral and metabolic intake responses to stimuli related to feeding or the environment.

One of the major concerns in evaluating intake is feed refusal due to palatability (Van Soest, 1994). Feeding corn steep liquor, which has a bitter taste with a $\mathrm{pH}$ value of 3.7 (Mirza \& Mushtaq, 2006), can decrease intake. Forbes (1999) reported that animals are born with innate preferences and aversions to certain foods and that mammals prefer sweet foods and avoid bitter ones. Therefore, the lower intake of corn steep liquor can be explained by the reduced palatability.

A linear decrease in the dry matter intake (DMI) was observed by Silva et al. (2008), who replaced five dietary corn steep liquor levels $(0.0,3.5,7.0,10.5$ and $14.0 \%)$ with soybean meal in the diet of lactating cows yielding $15 \mathrm{~kg} / \mathrm{d}$ of milk. This finding can be attributed to the bitter taste of the product, i.e., the psychogenic factor.

Replacing soybean meal with cottonseed meal plus urea was tested in cows with an average MY of $11.55 \mathrm{~kg} / \mathrm{d}$ by Silva (2008), who observed no treatment effect on DMI. Similar results were obtained by Alves (2008), Pina et al. (2006) and Bernard (1997), who evaluated cottonseed meal-based diets for lactating cows. Solomon et al. (2000) evaluated soybean meal and extruded whole soybean-based diets in the diet of cows yielding $36.6 \mathrm{~kg} / \mathrm{d}$ and noticed that DMI was higher for the cows fed the extruded whole soybean-based diets.

No treatment effect $(\mathrm{P}>0.05)$ occurred for DMI, CPI, NDFI or TDNI for cows fed cottonseed meal and semi-integral soybean meal compared with the control, following the DMI result. Lower $(\mathrm{P}<0.05)$ nutrient intakes were observed for the animals fed corn steep liquor, due to the lower DMI and the differences in the dietary NDF and TDN concentrations (Table 1).
Feeding cottonseed meal, semi-integral soybean meal and corn steep liquor increased $(\mathrm{P}<0.05)$ EEI compared with the control. Animals consuming cottonseed meal and semi integral soybean meal had a greater EEI likely due to the high content of this nutrient in the feed (Table 1). However, the lower $(\mathrm{P}<0.05)$ EEI of cows fed corn steep liquor is likely related not only to the low EE content but also to the lower DMI observed for the animals fed this treatment.

Animals consuming cottonseed meal had a higher $(\mathrm{P}<0.05)$ NDFI $(\mathrm{g} / \mathrm{kg} \mathrm{BW})$ than those fed the control, due to the higher NDF content of this feed ingredient (Table 1). A lower NDFI $(\mathrm{g} / \mathrm{kg} \mathrm{BW})(\mathrm{P}<0.05)$ was detected for animals consuming corn steep liquor than for those fed soybean meal, which can be attributed to the absence of NDF in the composition of the corn steep liquor compared with soybean meal (Table 1).

The average dietary NDF content found in this study was $332.6 \mathrm{~g} / \mathrm{kg}$ and ranged from 307.6 to $358.7 \mathrm{~g} / \mathrm{kg}$. The dietary roughage:concentrate ratio was of 58:42. According to Mertens (1994), intake is limited by the filling effect of the diet when the NDF content is greater than 500 to $600 \mathrm{~g} / \mathrm{kg}$.

An average NDF intake of $10.0 \mathrm{~g} \mathrm{BW} / \mathrm{d}$, ranging from 0.87 to $11.0 \mathrm{~g} \mathrm{BW} / \mathrm{d}$, was observed in this study. This finding shows that intake was not limited by physical mechanisms. Mertens (1992) summarized the data from several experiments and estimated that the daily NDF intake was $1.2 \mathrm{~g} / \mathrm{kg} \mathrm{BW}$.

Animals consuming cottonseed meal, semi-integral soybean meal and corn steep liquor had a lower NFCI $(\mathrm{P}<0.05)$ than those fed soybean meal (control). The results observed for cottonseed meal and semi-integral soybean meal can be attributed to the variation in the composition of these feeds relative to the other nutrients used for the 
NFC calculation (Table 1). The lower NCFI of animals fed corn steep liquor is likely due to the lower DMI.

The digestibility coefficients for DM, OM, CP, EE and NDF of the corn steep liquor-based diet were lower $(\mathrm{P}<0.05)$ than those of the soybean meal-based diet (Table 5). Despite the lower DMI, animals consuming corn steep liquor showed lower digestibility, which can be attributed to a potential increase in the passage rate as it was fed in the liquid form.

The digestibility coefficient for the NDF of the corn steep liquor-based diet was $33.7 \%$ lower than that of the soybean meal-based diet, which was likely due to the reduced rumen $\mathrm{pH}$. In fact, cows fed the corn steep liquorbased diet consumed less NDF (Table 3) and a lower NDFI reduces salivation, which favors a lower ruminal $\mathrm{pH}$ and changes in the microbial cellulolytic media, thereby affecting feed digestibility (Mertens, 1992).

No effect $(\mathrm{P}>0.05)$ on NFC digestibility occurred for the control diet, although animals consuming corn steep liquor had lower NFC intake (Table 4). This behavior was expected to be a component of a highly digestible diet (NRC, 2001).

The low digestibility coefficients for the corn steep liquor-based diet is related to the TDN content, which was lower $(\mathrm{P}<0.05)$ than that found for the control.

Animals consuming cottonseed meal and semi-integral soybean meal had a higher $(\mathrm{P}<0.05) \mathrm{CP}$ digestibility and those fed the cottonseed meal-based diet showed a greater urea content than those fed the soybean meal-based diet, suggesting that higher $\mathrm{CP}$ digestibility was obtained for the cottonseed meal-based diet because urea is rapidly soluble in the rumen. In a previous study, animals consuming soybean meal and soybean meal-based diet plus $50 \mathrm{~g} / \mathrm{kg}$ urea had greater crude protein digestibility and those fed cottonseed meal showed lower digestibility, with 280 and $380 \mathrm{~g} / \mathrm{kg} \mathrm{CP}$, respectively (Pina et al., 2006).
Animals consuming semi-integral soybean meal had higher crude protein digestibility than those fed the soybean meal-based diet, which was likely due to the extrusion. Extrusion is one of the processes used to obtain semi-integral soybean, and it reduces the particle size so that the feed is more extensively degraded by the rumen microorganisms (Teixeira et al., 1999), resulting in an increase in digestibility. This hypothesis is supported by Herkelman \& Cromwell (1990), who affirmed that extrusion is one of most efficient processes to maintain the chemical composition and increase the protein and fat digestibility of soybean.

The milk yield and fat-corrected milk yield were lower $(\mathrm{P}<0.05)$ for those animals consuming corn steep liquor than for those fed soybean meal (Table 6), likely due to the lower dry matter intake, crude protein intake and TDN contents and lower digestibility of the corn steep liquorbased diet (Tables 4 and 5).

The results herein presented regarding the milk yield for cows that consumed cottonseed meal are somewhat similar to those of Alves (2008), Silva (2008) and Pina et al. (2006), who reported that cottonseed meal maintains milk yield relative to soybean meal. Silva et al. (2008) found no treatment effect on milk yield for animals that consumed corn steep liquor, but these authors worked with a daily milk yield of $14.22 \mathrm{~kg}$, which corresponds to animals that require low-quality diets.

No effect $(\mathrm{P}>0.05)$ on milk fat concentration was observed when the treatments were compared with the control; however, the animals that consumed the cottonseed meal and corn steep liquor showed a greater $(\mathrm{P}<0.05)$ daily fat production $(\mathrm{kg})$ than those fed soybean meal. The lower value found for the corn steep liquor-based diet is likely due to the low milk production. Reasons for the low fat production of the cottonseed meal-based diets include a lower fat percentage and lower milk yield than the soybean meal based-diet.

Table 5 - Effect of alternative protein sources on total tract nutrient digestibility and dietary TDN of dairy cows

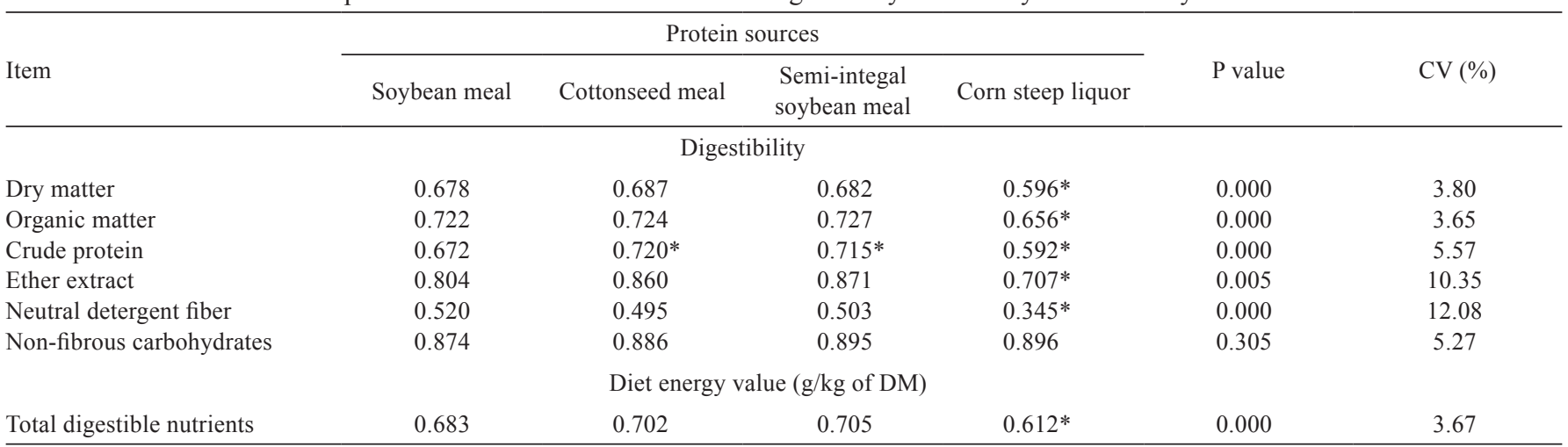


Table 6 - Effect of alternative protein sources on performance, milk composition, dry matter and efficiency of $\mathrm{N}$ utilization of dairy cows

\begin{tabular}{|c|c|c|c|c|c|c|}
\hline \multirow[b]{2}{*}{ Item } & \multicolumn{4}{|c|}{ Protein sources } & \multirow[b]{2}{*}{$\mathrm{P}$ value } & \multirow[b]{2}{*}{$\mathrm{CV}(\%)$} \\
\hline & Soybean meal & Cottonseed meal & $\begin{array}{l}\text { Semi-integral } \\
\text { soybean meal }\end{array}$ & Corn steep liquor & & \\
\hline Milk yield (kg/d) & 24.13 & 22.64 & 23.44 & $20.58 *$ & 0.041 & 10.22 \\
\hline Fat corrected milk yield $-3.5 \%(\mathrm{~kg} / \mathrm{d})$ & 1) 26.10 & 23.60 & 24.40 & $22.40 *$ & 0.040 & 9.45 \\
\hline Fat $(\mathrm{g} / \mathrm{kg})$ & 40.0 & 37.5 & 37.5 & 40.5 & 0.029 & 5.84 \\
\hline Fat $(g / d)$ & 960.00 & $851.00 *$ & 881.10 & $831.90 *$ & 0.044 & 9.78 \\
\hline Protein $(\mathrm{g} / \mathrm{kg})$ & 33.1 & 32.5 & $31.9 *$ & 34.2 & 0.003 & 3.23 \\
\hline Protein (g/d) & 788.50 & 733.03 & 744.14 & 695.82 & 0.159 & 10.36 \\
\hline Lactose (g/kg) & 44.5 & 43.1 & 44.3 & 43.4 & 0.409 & 4.35 \\
\hline Total solids (g/kg) & 124.6 & $119.9 *$ & 120.8 & 125.1 & 0.022 & 2.98 \\
\hline Feeding efficiency ${ }^{1}$ & 1.00 & 1.10 & 1.02 & $1.26^{*}$ & 0.000 & 8.83 \\
\hline Nitrogen use efficiency ${ }^{2}$ & 0.25 & $0.22 *$ & 0.23 & 0.25 & 0.023 & 9.31 \\
\hline
\end{tabular}

CV - coefficient of variation.

Means in a row differ $(\mathrm{P}<0.05)$ from control by the Dunnett test.

${ }^{1}$ Fat corrected milk (3.5\%)/DMI (kg/d).

${ }^{2}$ Milk total N/Consumed total N (kg/d).

Animals fed a semi integral soybean meal-based diet showed a lower $(\mathrm{P}<0.05)$ milk protein percentage compared with the control. The semi-integral soybean meal diet provided a higher lipid content compared with the soybean meal diet. Others have suggested that increasing the energy proportion from the oxidation of fatty acids in the mammary glands alters blood flow and amino acid availability for incorporation in to milk (Palmquist \& Mattos, 2006). In a review, Wu \& Huber (1994) concluded that fat supplementation is related to reduction in milk proteins. Solomon et al. (2000) observed a lower protein percentage for cows yielding $36.6 \mathrm{~kg} / \mathrm{d}$ of milk and fed extruded whole soybean to replace soybean meal.

Animals that consumed cottonseed meal had lower $(\mathrm{P}<0.05)$ total solids compared with those fed soybean meal, likely due to the lower lactose and fat contents in the milk of these animals.

Animals fed corn steep liquor showed a greater $(\mathrm{P}<0.05)$ efficiency of DM utilization and a lower milk yield than those fed soybean meal. Although they showed a lower DMI, these animals also had a lower intake of crude protein and TDN. Despite limitations due to the weight variation in the Latin square design, the animals that consumed the corn steep liquor showed a weight loss $(434.52 \mathrm{~g} / \mathrm{d})$, and may have mobilized body tissue reserves for milk yield.

Wagner et al. (1983) conducted three trials comparing cottonseed meal and corn steep liquor-based diets and reported that both lactating primiparous and non-lactating cows fed corn steep liquor lost weight. This variation is likely due to the decreasing dry matter intake.

Animals that consumed cottonseed meal had a lower $(\mathrm{P}<0.05)$ efficiency of $\mathrm{N}$ utilization than those fed soybean meal. The uniformity in nitrogen intake showed possible differences in the quality of nitrogen sources used. The diet containing cottonseed meal had higher levels of urea, which may have led to an inefficient use of nitrogen. Pina et al. (2006) also found lower nitrogen use efficiency of animals that consumed cottonseed meal than those fed soybean meal-based diets.

\section{Conclusions}

The replacement of soybean meal by semi-integral soybean meal is possible because the main variables, such as dry matter intake, milk yield and milk composition did not change.

\section{References}

ALVES, A.F. Substituição do farelo de soja por farelo de algodão de alta energia na dieta de vacas em lactação. 2008. 76f. Dissertação (Mestrado em Ciência Animal) - Universidade Federal do Mato Grosso, Cuiabá.

BERNARD, J.K. Milk production and composition responses to source of protein supplement in diets containing wheat middlings. Journal of Dairy Science, v.80, n.5, p.938-942, 1997.

BRODERICK, G.A. Effects of varying dietary protein and energy levels on the production of lactating dairy cows. Journal of Dairy Science, v.86, n.4, p.1370-1381, 2003.

DETMANN, E., SOUZA, M.A., VALADARES FILHO, S.C. Métodos para análise de alimentos. Visconde do Rio Branco: Universidade Federal de Viçosa, 2012. 214p.

FERREIRA, M.A.; SILVA, F.M.; BISPO, S.V. et al. Estratégias na suplementação de vacas leiteiras no semi-árido do Brasil. Revista Brasileira de Zootecnia, v.38, p.322-329, 2009 (supl. especial).

FORBES, J.M.; HEIDE, D.; HUISMAN, E.A. Natural feeding behavior and feed selection. In: ZODIAC SYMPOSIUM, 5., 1999, Wageningen. Proceedings... Wageningen: Zodiac Symposium, 1998. p.3-12.

HERKELMAN, K.L.; CROMWELL G.L. Utilization of full-fat soybeans by swine reviewed. Feedstuffs, v.62, n.17, p.15-22, 1990 .

INSTITUTO DE TECNOLOGIA DE PERNAMBUCO - ITEP. [2009]. Climatologia. Available at: <http://www.itep.br/LAMEPE.asp $>$ Accessed on: June 23, 2010. 
LIMA, J.B.M.P.; GRAÇA, D.S.; BORGES, A.L.C.C. et al. Uso do óxido crômico e do LIPE $^{\circledR}$ na estimativa do consumo de matéria seca por bezerros de corte. Arquivos Brasileiros de Medicina Veterinária e Zootecnia, v.60, n.5, p.1197-1204, 2008.

LOPES FILHO, J.F. Avaliação da maceração dinâmica do milho após um curto período de hidratação e subsequente quebra no pericarpo do grão. Ciência e Tecnologia dos Alimentos, v.19, n.3, p.332-325, 1999.

MERTENS, D.R. Análise da fibra e sua utilização na avaliação de alimentos e formulação de rações. In: SIMPÓSIO INTERNACIONAL DE RUMINANTES, 29., 1992, Lavras. Anais... Lavras: Sociedade Brasileira de Zootecnia, 1992. p.188-219.

MERTENS, D.R.; FAHEY, G.C.; COLLINS, M. et al. Regulation offorage intake. In: FAHEY JR., G.C.; COLLINS, M.; MERTENS, D.R. et al. (Eds.). Forage quality, evaluation and utilization. Madison, Wisconsin: American Society of Agronomy, Crop Science Society of American and Soil Science Society of America, 1994. p.450-493.

MIRZA, M.A.; MUSHTAQ, T. Effect of supplementing different levels of corn steep liquor on the post-weaning growth performance of pak-karakul lambs. Pakistan Veterinary Journal, v.26, n.3, p.135-137, 2006.

NATIONAL RESEARCH COUNCIL - NRC. Nutrient requirements of dairy cattle. 7.ed. Whashington, D.C.: National Academic Press, 2001. 381p.

PALMQUIST, D.L.; MATTOS, W.R.S. Metabolismo de lipídeos. In: BERCHIELlE T.T.; PIRES, A.V.; OLIVEIRA, S.G. (Eds.) Nutrição de ruminantes. Jaboticabal: FUNEP, 2006. p.287-309.

PERES, J.R. O leite como ferramenta do monitoramento nutricional. In: GONZÁLEZ, F.H.D.; DURR, J.V.; FONTANELI, R.S. (Eds.) Uso do leite como ferramenta do monitoramento nutricional. Porto Alegre: Universidade Federal do Rio Grande do Sul, 2000. p.30-45.

PINA, D.S.; VALADARES FILHO, S.C.; VALADARES, R.F.D. et al. Consumo e digestibilidade aparente total dos nutrientes, produção e composição do leite de vacas alimentadas com dietas contendo diferentes fontes de proteína. Revista Brasileira de Zootecnia, v.35, n.4, p.1543-1551, 2006.

SANTOS, F.A.; SANTOS, J.E.P.; THEURER, C.B. et. al. Effects of rumen-undegradable protein on dairy cow performance: a 12 year literature review. Journal of Dairy Science, v.81, n.12, p.3182-3213, 1998.

SENGER, C.C.D.; KOZLOSKI, G.V.; SANCHEZ, L.M.B. et al. Evaluation of autoclave procedures for fibre analyses in forage and concentrate feedstuffs. Animal Feed Science and Technology, v.146, n.1, p.169-174, 2008.
SILVA, J.D.; QUEIROZ, A.C. Análise de alimentos (Métodos químicos e biológicos). 3.ed. Viçosa, MG: Universidade Federal de Viçosa, 2002. 235p.

SILVA, F.M. Substituição do farelo de soja pelo farelo de algodão corrigidocom uréia em dietas à base de palma forrageira para vacas emlactação. 2008. 37f. Dissertação (Mestrado em Zootecnia) - Universidade Federal Rural de Pernambuco, Recife.

SILVA, M.J.M.; FERREIRA, M.A.; MELO, A.A.S. et al. Níveis de inclusão do resíduo do milho (mazoferm), em substituição ao farelo de soja para vacas em lactação. Acta Scientiarum. Animal Sciences, v.30, n.1, p.51-57, 2008.

SKLAN, D.; MOALLEM, U.; FOLMAN, Y. Fatty acids,calcium soaps of fat acids, and cottonseeds fed to high yieldingcows. Journal of Dairy Science, v.75, n.9, p.2463-2472, 1991.

SNIFFEN, C.J.; O'CONNOR, J.D.; VAN SOEST, P.J. et al. A net carbohydrate and protein system for evaluating cattle diets; II. Carbohydrate and protein availability. Journal of Animal Science, v.70, n.11, p.3562-3577, 1992

SOLOMON, R.; CHASE, L.E.; BEN-GHEDALIA, D. et al. The effect of nonstructural carbohydrate and addition of full fat extruded soybeans on the concentration of conjugated linoleic acid in the milk fat of dairy cows. Journal of Dairy Science, v.83, n.6, p.1233-1329, 2000.

TEIXEIRA, J.C.; DELGADO, E.F.; CORREA, E.M. et al. Cinética da digestão ruminal da amiréia 45-S em vacas da raça Holandesa. Ciência Agrotécnica, v.23, n.3, p.719-723, 1999.

VALADARES FILHO, S.C.; BRODERICK, G.A.; VALADARES, R.F.D. et al. Effect of replacing alfalfa silage with high moisture corn on nutrient utilization and milk production. Journal of Dairy Science, v.83, n.1, p.106-114, 2000.

VAN SOEST, P.J. Nutritional ecology of the ruminant. 2.ed. London: Constock Publishing Associates, 1994. 476p.

VAN SOEST, P.J.; ROBERTSON, J.B.; LEWIS, B.A. Methods for dietary fiber, neutral detergent fiber, and nonstarch polysaccharides in relation to animal nutrition. Journal of Dairy Science, v.74, n. 10, p.3583-3597, 1991.

WAGNER, J.J.; LUSBY, K.S.; HORN, G.W. Condensed molasses soluble, corn steep liquor and fermented ammoniated condensed whey as protein sources for beet cattle grazing dormant native range. Journal Animal Science, v.57, n.3, p.542-552, 1983.

WEISS, W.P. Energy prediction equations for ruminant feeds. In: CORNELL NUTRITION CONFERENCE FOR FEED MANUFACTURERS, 61., 1999, Proceedings... Ithaca: Cornell University, 1999. p.176-185.

WU, Z.; HUBER, J.T. Relationship between dietary fat suplementation and milk protein concentration in lactating cows: a review. Livestock Production Science, v.39, n.2, p.141-155, 1994. 